\title{
Prospective clinical study of transverse development with orthodontics with self-ligating brackets
}

\author{
Maria E. Mateu, Sandra Benítez-Rogé, Diana Calabrese, María Lumi, Marina Iglesias, \\ Paola Méndez, Marisa Solla, Alejandra A. Folco.
}

Universidad de Buenos Aires, Facultad de Odontología, Cátedra de Ortodoncia, Buenos Aires, Argentina

\begin{abstract}
Orthodontics with low friction, low force, passive self-ligating brackets produces alveolar-dental remodeling, resulting in an increase in the transverse diameter of the dental arches, especially in the premolar sector.

The aim of this study was to compare the modifications of the transverse diameter in the pre-and post-dental alignment cast models with orthodontics with passive self-ligating brackets in patients with moderate to severe dental discrepancy.

The study included 28 patients of both sexes aged 16 to 48 years with dental discrepancies between -6 and $-16 \mathrm{~mm}$, treated with self-ligating Damon brackets and thermally activated NickelTitanium-Copper arches.

With a digital pachymeter, Mitutoyo brand, five measurements were taken per dental arch: distance between canines (C), first premolars (IPM), second premolars (2 PM), first molars (1M)
\end{abstract}

and second molars (2M), before and after orthodontic alignment. The variations were statistically evaluated by Student T Test for paired samples.

Average distance between teeth varied with dental alignment in both jaws. The greatest increases in transverse diameter were recorded in the premolar areas. Minor though statistically significant variations also occurred in the $2 M$ of the maxilla and in the $C$ of the mandible In alignment with passive self-ligating brackets, there is an increase in the transverse diameter due to the development of the dental arches, mainly in the premolar sector of both jaws and also at the level of the canines in the mandible. Received: February 2020; Accepted: June 2020.

Keywords: orthodonctic brackets- malocclusion- tooth movement techniques.

\section{Estudio clínico prospectivo del desarrollo transversal con ortodoncia con brackets autoligables}

\begin{abstract}
RESUMEN
La ortodoncia con brackets autoligables pasivos, de baja fricción y baja fuerza, produce remodelación alvéolodentaria; con aumento del diámetro transversal de las arcadas, especialmente en el sector de los premolares. El objetivo de este trabajo fue comparar las modificaciones del diámetro transversal en los modelos de yeso pre y post alineación dentaria con ortodoncia con brackets autoligables pasivos en pacientes con discrepancia dentaria moderada a severa. El estudio incluyó 28 pacientes de ambos sexos de entre 16 y 48 años de edad con discrepancia dentaria entre -6 y-16mm, tratados con brackets autoligables sistema Damon y arcos termo activables de Níquel-Titanio-Cobre. Con un paquímetro digital marca Mitutoyo, se tomaron 5 medidas por arcada: distancia entre caninos $(C)$, primeros y segundos premolares (1 PM y 2 PM) y primeros y segundos molares (1M y 2M); pre
\end{abstract}

y post alineación ortodóncica. Las variaciones registradas fueron evaluadas estadísticamente mediante Student T Test para muestras apareadas. La distancia promedio entre dientes varió con la alineación dentaria en ambos maxilares. Los mayores aumentos del diámetro transversal se registraron en las zonas de los premolares. Se produjeron también variaciones menores, aunque estadisticamente significativas, en los $2 \mathrm{M}$ del maxilar superior y en los $C$ del maxilar inferior. En la alineación con brackets autoligables pasivos, hay incremento del diámetro transversal por desarrollo de las arcadas, principalmente en el sector premolar de ambos maxilares y en el maxilar inferior también a nivel de los caninos.

Palabras clave: brackets de ortodoncia- maloclusión- técnicas de movimiento dentario. 


\section{INTRODUCTION}

Since self-ligating brackets appeared in 1935, numerous papers have been published with the intention of determining the advantages of the selfligating system over the conventional ${ }^{1-6}$.

Self-ligating brackets reduce ligating friction, and the use of super elastic archwires enables the application of light forces that produce tooth movements. These are the forces of choice in orthodontic treatments. The clinical response of low friction systems and light forces with self-ligating brackets is different from that obtained in friction systems with conventional brackets. In a comparative study between treatment with conventional and selfligating brackets, Herradine ${ }^{5}$ found lower incisor inclination in self-ligating braces and expansion in both systems.

Reddy et al. ${ }^{7}$ found that for space closing, treatments with self-ligating brackets were more efficient than conventional brackets, and the alignment occurred with less incisor inclination.

Lineberger ${ }^{8}$ carried out a study of digital models in which a control group of 25 untreated patients was compared to 25 patients treated with self-ligating brackets (DAMON). In the Damon-treated group, there was an increase in the transverse diameter in the premolar area from 2 to $2.2 \mathrm{~mm}$. There is no reference in the inclusion criteria to the need for space required for alignment (crowding), patients with Angle Class I canine and molar were included. Morais et $\mathrm{al}^{9}$, found a significant increase in the transverse diameter in the dental arches in patients that were treated with self-ligating brackets, especially between first premolars. It determined that the widening occurred mainly by buccal inclination. Our hypothesis is that in patients with moderate to severe crowding treated with self-ligating brackets, the greatest gain in space occurs in the premolar area, achieving the natural dental arch shape, giving space to the aligning teeth.

The aim of this study is to evaluate in pre- and postalignment models the differences in the distance in both jaws between canines, first premolars, second premolars, first molars and second molars.

\section{MATERIALS AND METHODS}

The project was approved by the Bioethics Commission of the School of Dentistry of the University of Buenos Aires, code CO22, 20122014.
The study began with 31 patients aged 16 to 48 years old who were treated at the Orthodontic Department of the School of Dentistry of the University of Buenos Aires. Patients with systemic diseases, joint disorders, periodontitis, untreated caries, mixed or temporary dentition and with impacted or absent teeth (except third molars) were excluded. All patients signed their informed consent to participate in this project. Three patients discontinued treatment for personal reasons, so the final number of subjects included in the study was $28-10$ male and 18 female. These 28 patients needed dental arch expansion due to moderate to severe dental crowding (dental discrepancy between -6 and $-16 \mathrm{~mm}$ ).

Patients were treated with the Damon System (low friction system), Damon II brackets (A-Company) and copper nickel-titanium archwires (Damon $\mathrm{Cu}-\mathrm{NiTi} 0.014$ and 0.016), Damon format archwires. Each treatment plan was prepared according to the initial diagnosis with or without indication of dental extractions. If necessary, the extractions were performed after the alignment stage. Routine diagnostic studies were performed (Panoramic x-ray, lateral cephalometric radiograph; cephalometric tracings, clinical examination and dental models). The dental arch was considered aligned when it was possible to place the rectangular arch. No tooth extractions or interproximal stripping were performed in this initial stage of treatment. Impressions were taken for plaster casts for evaluation of the post-alignment stage.

The distance between homologous teeth was measured on the casts of the maxilla and mandible before and after treatment (Fig1). The measurement method was described in a previous work. ${ }^{10}$

A Mitutoyo Digimatic NTD12-6" C brand digital caliper was used; Mitutoyo Corp. Tokyo, Japan. Three calibrated operators performed the measurements.

The differences between pre- and post-treatment were statistically evaluated using the two-tailed Paired-Samples Student's T-Test.

\section{RESULTS}

The measurements are shown in Table 1. The differences between the pre- and post-treatment measurements in the maxilla were statistically significant for $2 \mathrm{PM}, 1 \mathrm{M}$ and $2 \mathrm{M}$. In the mandible, significant differences were found for canines and premolars. 


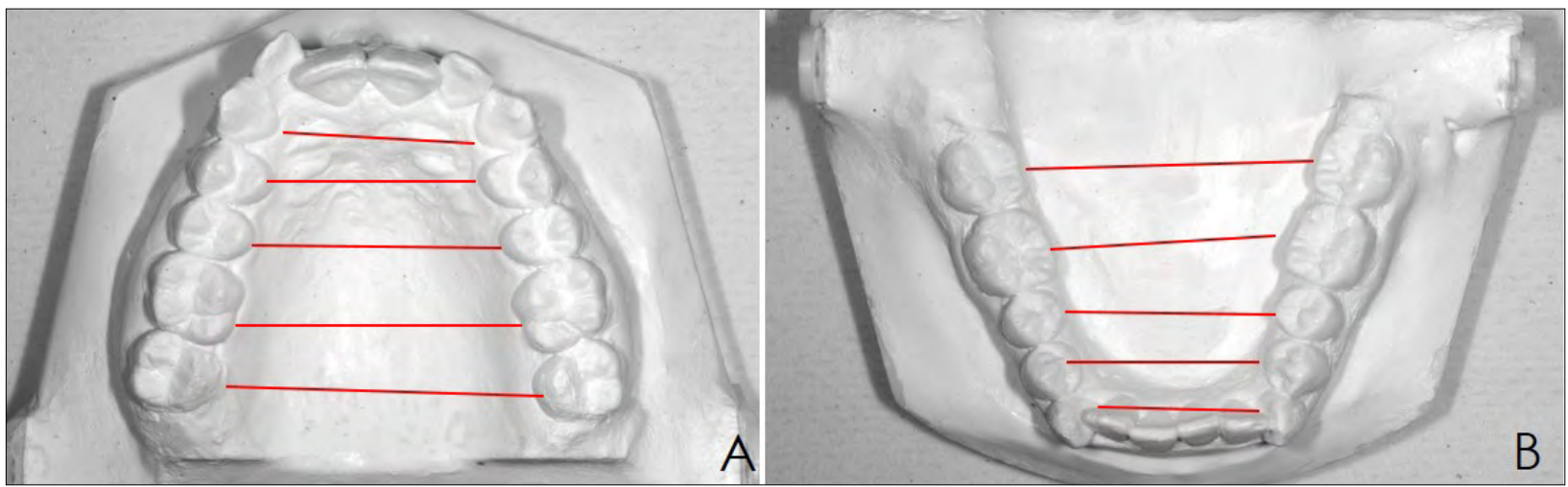

Fig. 1: Five measurements were taken per patient per jaw, between canines, first premolars, second premolars, first molars, and second molars, before and after dental alignment. A: Maxilla B: Mandible.

\section{DISCUSSION}

The treatment with the Damon System uses selfligating brackets and Damon Copper Ni-Ti archwires ${ }^{1}$ (copper-nickel-titanium) with thermal-reactive properties, which deliver very low force that could be controlled by the musculature. The size of the arches is the same for both jaws, being larger in relation to other formats such as the "True Arch" of the Roth philosophy ${ }^{11}$ or the formats established for treatment with the MBT System designed to respect the original shape of each arch: ovoid, narrow or square, with different sizes for maxilla and mandible The material used in the alignment phase is nickel titanium. ${ }^{12}$

Clinical studies comparing self-ligating and conventional brackets include patients with mild to moderate crowding because a patient with severe crowding could not be treated with conventional orthodontics without having to be initially extracted 6,13-19.

These studies do not evaluate the results of treatment with self-ligating brackets in patients with crowding greater than $7 \mathrm{~mm}$ and the need for transverse arch development.

In the present study, moderate to severe crowding was used as an inclusion criterion to evaluate the results of treatment with self-ligating brackets by comparing dental arches before and after alignment with orthodontics.

Inter-canine distance had minimal variation for the maxilla, with a large deviation between cases. In the mandible, the pre- and post-treatment difference increased slightly on average, with less deviation between cases.

Regarding the variations in the premolar sector, a significant increase in transverse diameter was found for both premolars and in both dental arches.
Vajaria et al. ${ }^{14}$ included the evaluation of the distance between premolars, which was not taken into account in previous studies. In a retrospective study, they compared patients treated with the conventional and self-ligating systems. Despite the fact that the population studied was different from that of the present study, both in the inclusion criteria and in the lack of description on the degree of crowding, their results have the same trend as ours. It is inferred that transverse development occurs according to the need for space presented by each patient according to the compression or crowding in their dental arches. Due to the action exerted by the deflection of the archwire, remodeling occurs in the dental arches according to the space required by the teeth. The greatest transverse gain is found in the inter-premolar distance, which will be greater in the patient with the highest compression. The greatest compression in the premolar sector would be in relation to the lack of natural development of the dental arches,

\begin{tabular}{|c|c|c|c|c|}
\hline & \multicolumn{2}{|c|}{ Maxilla } & \multicolumn{2}{|c|}{ Mandible } \\
\hline & $X \pm S^{*}$ & p value ${ }^{\star \star}$ & $X \pm S D^{*}$ & p value ${ }^{\star *}$ \\
\hline Canines & $0.29 \pm 2.44$ & 0.34 & $0.82 \pm 1.28$ & $<0.01^{\star * *}$ \\
\hline $\begin{array}{c}1 \mathrm{st} \\
\text { premolars }\end{array}$ & $3.14 \pm 1.24$ & $<0.01^{* \star *}$ & $1.97 \pm 1.93$ & $<0.01^{\star \star *}$ \\
\hline $\begin{array}{l}\text { 2nd } \\
\text { premolars }\end{array}$ & $2.55 \pm 1.73$ & $<0.01^{* * *}$ & $2.1 \pm 1.59$ & $<0.01^{\star \star \star}$ \\
\hline 1st molars & $0.31 \pm 1.24$ & 0.19 & $0.38 \pm 1.46$ & 0.23 \\
\hline $\begin{array}{l}\text { 2nd } \\
\text { molars }\end{array}$ & $-0.72 \pm 1.49$ & $<0.01^{\star \star *}$ & $0.07 \pm 2.2$ & 0.86 \\
\hline
\end{tabular}


associated with alteration of oral functions. In the maxilla, distance increased slightly between first molars and decreased between second molars, with a statistically significant difference between the values. This would be related to the transverse compression observed in the pre-treatment models between premolars and first molars. The second molar presents a position toward the vestibular in the dental arch at the transverse level, possibly because it erupts protected from abnormal muscular activity by anatomical landmarks. In the mandible, both inter-molar distances increased slightly, with no statistically significant difference. The greatest modification in the transverse diameter of both upper and lower dental arches occurs at the level of the inter-premolar distance, coinciding with the studies by Cattaneo, ${ }^{10}$ Lineberger ${ }^{8}$ and two previous

\section{ACKNOWLEDGMENT}

We would like to thank the company BITE for providing supply of orthodontic materials. The authors declare that they have no conflicts of interest.

\section{FUNDING:}

This work was supported in part by a Grant from the University of Buenos Aires. Cod. 0020090200390. 2012- 2014 Program.

\section{REFERENCES}

1. Stolzenberg J. The Russell attachment and its improved advantages. Int J Orthod Dent Children,1935; 21: 837-840.

2. Eberting JJ, Straja SR, Tuncay OC. Treatment time, outcome, and patient satisfaction comparisons of Damon and conventional brackets. Clin Orthod Res. 2001; 4:228234.

3. Damon DH. The rationale, evolution and clinical application of the self-ligating bracket. Clin Orthod Res. 1998; 1:52-61

4. Damon DH. The Damon low friction bracket: a biologically compatible straight-wire system. J ClinOrthod. 1998; 32:670-680

5. Harradine NW. Self-ligating brackets and treatment efficiency. Clin Orthod Res. 2001; 4:220-227.

6. Javier Moyano J, Montagut D, Perera R, Fernández-Bozal J, Puigdollers A. Comparison of changes in the dental transverse and sagittal planes between patients treated with self-ligating and with conventional brackets. Dental Press J Orthod. 2020; 25:47-55

7. Reddy VB, Kumar TA, Prasad M, Nuvvula S, Patil RG, Reddy PK. A comparative in-vivo evaluation of the alignment efficiency of 5 ligation methods: A prospective randomized clinical trial. Eur J Dent. 2014;8:23-31.

8. Lineberger MB, Franchi L, Cevidanes LH, Huanca Ghislanzoni LT, Mc. Namara JA (Jr.). Three-dimensional digital cast analysis of the effects produced by a passive self-ligating system. Eur J Orthod. 2016;38:609-614. studies published by our group ${ }^{9-13}$. The originality of the present study is the inclusion in the sample of patients with moderate to severe crowding, in whom the teeth could remain in their basal areas without extractions, a result that could not have been achieved without the transverse development of the dental arches.

\section{CONCLUSION}

In alignment with passive self-ligating brackets in patients with moderate to severe crowding, there is a significant increase in transverse diameter due to the development of the dental arches, mainly in the premolar sector in both jaws. The greater transverse development in the maxilla would indicate that the appliance enlarges the dental arch that most needs it, even if the same arch format is used.

\section{CORRESPONDENCE:}

Dr. Alejandra A. Folco

Cátedra de Ortodoncia, Facultad de Odontología, UBA.

M.T. de Alvear 2142

1122, Ciudad de Buenos Aires

Argentina

ale.folco@hotmail.com

9. Morais J, Melsen B; Freitas K, Castello Branco N, Garib D, Cattaneo P. Evaluation of maxillary buccal alveolar bone before and after orthodontic alignment without extractions: A cone beam computed tomographic study. Angle Orthod. 2018; 88:748-756.

10. Folco A, Benítez-Rogé S, Calabrese D, Iglesias M, Lumi M, Hetch P, Mateu ME. Method for evaluation of transverse dimension in treatment with self-ligating orthodontic treatment. A comparative study. Acta Odontol Latinoam. 2017;30:124-128.

11. Roth RH: The Straight-Wire Appliance 17 years later. J Clin Orthod. 1987;21:632-642

12. Mc. Laughlin RP, Bennett JC, Trevisi HA. Clinical Review of the MBT ${ }^{\mathrm{TM}}$ Orthodontic Treatment Program. Orthodontic Perspectives, Vol. IV No. 2, 1997.

13. Mateu ME, Benítez Rogé S, Iglesias M, Calabrese D et al. Increased interpremolar development with self-ligating orthodontic. Prospective randomized clinical trial. Acta Odontol Latinoam. 2018;31:104-109.

14. Vajaria R, Begole E, Kusnoto B, Galang MT, Obrez A. Evaluation of incisor position and dental transverse dimensional changes using the Damon system. Angle Orthod. 2011;81:647-652.

15. Celar A, Schedlberge rM, Dórfler P, Bertl M. Systematic review on self-ligating vs. conventional brackets: initial pain, number of visits, treatment time. J Orofac Orthop. 2013; 74:40-51. 
16. Oltramari Navarro PVP, Navarro RL. Dentoalveolar mandibular changes with self-ligating versus conventional bracket systems: A CBCT and dental cast study. Dental Press J Orthod. 2015;20:50-57.

17. Atik E, Akarsu-Guven, Kocadereli, Ciger S. Evaluation of maxillary arch dimensions and inclination changes with self-ligating and conventional brackets using broad archwires. Am J Orthod Dentofacial Orthop. 2016;149:830837.
18. Almeida MR, Futagami C, Conti ACCF, Oltramari Navarro PVP, Navarro RL. Dentoalveolar mandibular changes with self-ligating versus conventional bracket systems: A CBCT and dental cast study. Dental Press J Orthod. 2015 ;20:5057.

19. Reddy VB, Kumar TA, Prasad M, Nuvvula S, Patil RG, Reddy PK. A comparative in-vivo evaluation of the alignment efficiency of 5 ligation methods: A prospective randomized clinical trial. Eur J Dent. 2014; 8:23-31. 